ТЕОРЕТИЧНИЙ АНАЛІЗ ПРОБЛЕМИ ГОТОВНОСТІ МАЙБУТНІХ ПСИХОЛОГІВ ДО РОБОТИ З НЕПОВНИМИ СІМ'ЯМИ

\title{
THEORETICAL ANALYSIS OF THE PROBLEM OF FUTURE PSYCHOLOGISTS READINESS TO WORK WITH SINGLE - PARENT FAMILIES
}

\begin{abstract}
Автором здійснено теоретичний аналіз наукових досліджень із вивчення питання готовності майбутніх психологів до професійної діяльності: більшість досліджень указує на те, що, крім набутих знань і практичних навичок і вмінь, певний ступінь підготовки майбутнього психолога-практика можливий за умови достатнього рівня оволодіння багатьма життєвими й соціальними компетенціями та самореалізації й передстартової активації свого «Я», наголошують на тому, що професійний та особистісний аспекти підготовки, які, у свою чергу, поєднані в єдину проблематику професійно-особистісного зростання, $\epsilon$ взаємозалежними й взаємозумовленими.

Проаналізовано психологічну готовність як складник просресійної підготовки майбутніх фахівців-психологів, який зумовлює наявність просресійно важливих особистісних якостей $і$ властивостей іє однією з необхідних умов ефрективного здійснення профресійної психологічноі допомоги сім'ям. Зібрано в таблицю напрями досліджень у контексті фрормування готовності психолога з вирішення різних конкретно поставлених завдань і встановлено, що на стан психологічної готовності справляють вплив конкретні умови, у яких відбувається діяльність. Уточнено сутність поняття «готовність майбутніх психологів до роботи з неповними сім'ями», яке здійснюється шляхом формування всіх їі компонентів. Обгрунтовано структурні компоненти цієї готовності: мотиваційно-ціннісний, когнітивно-пізнавальний, операційно-діяльнісний та особистісно-рефрлексивний, які є взаємозалежними, взаємодоповнюючими один одного і перебувають у динамічній взаємодії й тісному зв'язку між собою, характеризуючи цю готовність як цілісне системне утворення. За допомогою експертної роботи визначено профессійні, діяльнісні та психологічні ознаки, що висвітлюють зміст структурних компонентів готовності майбутніх психологів до роботи з неповними сім'ями.

Ключові слова: психологічна готовність, профресійна готовність, формування готовності, фрахівець, компоненти готовності, ознаки готовності.
\end{abstract}

The author carried out a theoretical analysis of scientific research on the study of the readiness of future psychologists for professional activity: most studies indicate that in addition to the acquired knowledge, practical skills and abilities, a certain degree of training of the future psychologist-practice is possible with a sufficient level of mastering many life and social competencies, self-realization and pre-start activation of their "I", emphasize that professional and personal aspects of training that, in turn, the combined problems of professional and personal growth are interdependent and interdependent. Psychological readiness is analyzed as a component of professional training of future specialists in psychology, which determines the presence of professionally important personal qualities and properties and is one of the necessary conditions for the effective implementation of professional psychological assistance to single-parent families. It is collected in a table of research directions in the context of the formation of a psychologist's readiness to solve various specific tasks and it is established that the state of psychological readiness is influenced by the specific conditions in which the activity takes place.

The essence of the concept of "readiness of future psychologists to work with single-parent families", which is carried out by forming all its components, is clarified. The structural components of this readiness are substantiated: motivational-value, cognitive-cognitive, operational-activity and personal-reflexive, which are interdependent, complementary to each other and are in dynamic interaction and close connection with each other, describing this readiness as an integral system education.

With the help of expert work, professional, activity and psychological features are identified that highlight the content of structural components of the readiness of future psychologists to work with single-parent families.

Key words: psychological readiness, professional readiness, formation of readiness, specialist, components of readiness, signs of readiness.
Постановка проблеми. Важливою передумовою успішного виконання будь-якої діяльності $€$ готовність до ії̈ здійснення. Готовність психолога до професійної діяльності потребує особливої уваги, оскільки зумовлює здатність фахівця розв'язувати складні спеціалізовані завдання й практичні проблеми в різних сферах психології, зокрема в сімейній.

Варто зазначити, що сімейна проблематика $€$ надзвичайно багатогранною і складною, адже соціальні процеси, що відбуваються в сучасному суспільстві, істотно впливають на стан сім'ї, динаміку й тенденції її розвитку. У зв'язку з нестабільною соціально-економічною та політичною ситуацією в нашій державі останніми роками спостерігаємо збільшення кількості неповних сімей, які потребують соціальної та психологічної підтримки, допомоги в збереженні, налагодженні чи відновленні зв'язків між їі членами, рекомендацій щодо соціалізації підростаючого покоління із зазначеної кризової категорії сімей, змістових порад 
із питань виконання й перерозподілу функцій сім'ї в умовах її структурної деформації. Таке соціальне замовлення й підтверджує актуальність дослідження та породжує потребу в цілеспрямованій підготовці майбутніх психологів до здійснення роботи з членами неповних сімей.

Аналіз останніх досліджень і публікацій. Дослідженню проблеми готовності до професійної діяльності приділяли увагу такі відомі вчені, як М. Дяченко, К. Дурай-Новакова, Е. Зеєр, Л. Кандибович, В. Панок, В. Рибалко, В. Сластьонін, Н. Чепелєва й інші $[7 ; 6 ; 8 ; 13$; $14 ; 16 ; 18]$. На думку більшості дослідників, професійна готовність майбутнього фахівця до діяльності є складним, багатоаспектним особистісним утворенням. Крім того, вона пов'язана з глибинними структурами особистості, з її ціннісно-смисловою сферою, розумінням призначення майбутньої професійної діяльності, знайомством із широким колом питань теоретичної та практичної психологічної підготовки, прикладними знаннями з психології, прагненням у процесі свого життя успішно інтегрувати в собі наукові знання й навички, здатністю до критичної перевірки процесів діяльності з метою рефлексії.

Серед багатьох питань, які тісно пов'язані з дослідженням цієї проблеми, є чимало таких, що стосуються вивчення питань взаємодії соціальних педагогів і вчителів з неповними сім'ями (неповні сім'ї, організація та зміст роботи з соціального захисту жінок, дітей і сімей - Т. Зубкова [9]; підготовка майбутнього вчителя початкової школи до роботи з батьками молодших школярів $з$ неповних сімей - А. Шульга [20]; психологічна допомога функціонально неповним сім'ям в освітньому закладі - І. Юрченко [21]) тощо. Водночас відсутні праці, у яких було б обґрунтовано специфіку й удосконалення практики професійної підготовки майбутніх психологів до роботи саме з неповними сім'ями.

Постановка завдання. Мета статті - здійснити теоретичний аналіз наукових досліджень із вивчення питання готовності майбутніх психологів до професійної діяльності.

Виклад основного матеріалу дослідження. У ході дослідження виявлено, що сьогодні існують різні підходи до визначення змісту поняття «Готовність», яке, у свою чергу, ототожнюється з поняттям «професійна готовність». Уважаємо, що поняття «підготовка» й «Готовність» дуже тісно пов'язані, взаємозалежні та взаємозумовлені. Це пояснюється тим, що підготовка до професії є ні що інше, як формування готовності до неї, а система настанов на працю, стійка орієнтація на виконання професійних функцій, загальна готовність до праці $€$ психічним результатом професійної підготовки. Відзначимо, що й трактування поняття «Готовність» зумовлено як специфікою структури конкретної діяльності, що досліджується в кожному конкретному випадку (робота у звичайних умовах, в аварійних ситуаціях, у спорті тощо), так і розходженням теоретичних підходів дослідників у вивченні цієї проблеми. Готовність до діяльності розглядається як на особистісному, так і на функціональному рівнях. Представники функціонального підходу М. Дяченко, Л. Кандибович, В. Сластьонін розуміють поняття «Готовність» як певний функціональний стан, установка на психологічні та соціальні взаємовідносини, що характеризує поведінку особистості [7; 21]. Цей підхід характеризується тим, що стан готовності зумовлюється стійкими психічними особливостями, властивими цій особистості. Він не являє собою перенесення якостей і станів у нову ситуацію, просту їх актуалізацію. На думку В. Сластьоніна [16], готовність до діяльності $є$ особливим психічним станом, який характеризується наявністю в суб'єкта образу, структури певної дії та постійної спрямованості свідомості на її виконання. На нашу думку, на стан психологічної готовності справляють вплив також конкретні умови, у яких відбувається діяльність. Із цього погляду готовність як функціональний стан містить різні установки щодо осмислення завдання, моделі ймовірної поведінки, визначення соціальних способів діяльності, оцінку власних можливостей у ї співвідношенні з майбутніми труднощами, а також необхідністю досягнення певного результату [5].

За визначенням К. Дурай-Новакової [6], професійна готовність $€$ не лише результатом, а й метою професійної підготовки, початковою й основною умовою ефективної реалізації можливостей кожної особистості. У фундаментальному дослідженні готовності студентів до педагогічної діяльності вчена визначає готовність як складне структурне утворення, центральним ядром якого $€$ позитивні установки, мотиви й усвідомлення цінності педагогічної праці. До складу готовності входять також комплекс професійно-педагогічних знань, навичок і вмінь, а також певний досвід їх застосування на практиці. Показники професійної готовності, безумовно, пов'язані з особистістю та діяльністю. Якщо готовність функціонує в певний обмежений проміжок часу, тоді їі можна назвати станом; якщо готовність проявляється в різні періоди під впливом мотиваційних факторів і ситуацій, тоді варто говорити про готовність як про якість особистості. У структурі професійної готовності дослідниця виділяє такі компоненти: мотиваційний, пізнавально-оцінний, емоційно-вольовий, операційно-дієвий, мобілізаційний.

На особливу увагу заслуговує дослідження характеристик поняття готовності до професійної діяльності Е. Зеєра [8], який розглядає 
готовність як складне особистісне утворення на двох рівнях. На першому рівні готовність розглядається як бажання, прагнення оволодіти якоюсь професією, спеціальністю, на другому - як здатність, підготовленість до професійної діяльності. Відповідно до першого рівня, компонентний склад визначають таким: мотиваційний: потреба в праці, зацікавленість професією, спеціальностями; уявлення про соціальний статус, престижність професії, матеріальна зацікавленість; пізнавальний: розуміння соціальної значущості, необхідності обраної професії, знання шляхів досягнення мети; емоційний: гордість за професію, естетичне ставлення до професійної майстерності; вольовий: уміння мобілізувати свої сили, подолати труднощі на шляху досягнення мети. На другому рівні готовність до професійної діяльності розглядається як уже сформованість необхідних для її успішного здійснення якостей (професійних, особистісних), умінь, навичок, знань.

Найбільш оптимальне, на нашу думку, тлумачення поняття готовності до професійної діяльності, що інтегрує попередній науковий досвід вивчення цього феномена, пропонують С. Максименко й О. Пелех: «Готовність до того чи іншого виду діяльності є цілеспрямованим вираженням особистості, що включає її переконання, погляди, ставлення, мотиви, почуття, вольові та інтелектуальні якості, знання, навички, уміння, установки» [12, с. 70]. Автори розрізняють тимчасову й тривалу готовність. Для ефективної професійної діяльності необхідний актуалізований стан тимчасової готовності. Він передбачає наявність стійкої сукупності рис тривалої готовності, котра, у свою чергу, мала пройти складний процес формування, динамічним стрижнем якого є оволодіння професією в умовах навчального закладу [12, с. 72].

Окремі думки щодо базових ознак діяльності практичних психологів, вимог до особистості майбутніх фахівців, особливостей підготовки майбутніх психологів представлені в роботах вітчизняних дослідників (Н. Берегової, В. Бочелюка, С. Максименко, А. Руденок, В. Панка, О. Пелех, Н. Чепелєвої, О. Черепєхіної та ін.) [3; 5; 12; 15; 13; 18; 19].

Як зазначають С. Максименко, В. Панок, Н. Чепелєва [12; 18], саме тому за час навчання в закладі вищої освіти студенти повинні не тільки набути необхідні знання з фахових дисциплін, а й розвинути відповідні психологічні якості, сформувати позитивне ставлення до майбутньої професії, від чого повною мірою буде залежати успішність творчої реалізації в практичній діяльності, а також реалізація власних здібностей робить особистість психологічно зрілою, здатною до творчості.

Аналіз наукових праць із проблеми дослідження формування готовності психолога до професійної діяльності в різних аспектах її вивчення (таблиця 1) дає змогу стверджувати, що майбутнього фахівця-психолога потрібно готувати до взаємодії з неповними сім'ями, так як така підготовка сприятиме підготовленості до стабільної продуктивної праці й комплексному та якісному виконанню функцій, завдань у процесі надання допомоги всім членам сімей із зазначеної кризової категорії та розумінню самим майбутнім фахівцем важливості й соціальної значущості такої взаємодії.

Автори по-різному визначають і висвітлюють процес формування готовності залежно від специфіки трудової діяльності, кожен із виділених компонентів у різних моделях чи дослідженнях має своє розуміння й навантаження.

Дослідник професійної рефлексії М. Бадалова [1], крім розробки психологічного комплексу методик на визначення рівня інтелектуальної готовності майбутніх психологів до розв'язання інтелектуальних завдань, для глибокого відображення компонентів цієї готовності, визначила умови формування інтелектуальної готовності студентів до розв'язання інтелектуальних завдань.

У дослідженні Н. Берегова [3] зазначає, що психологічна готовність до того чи іншого виду діяльності $є$ цілеспрямованим виявом особистості, який включає переконання, погляди, систему ставлень, мотиви, почуття, вольові та інтелектуальні якості, знання, навички, уміння, настанови. Така готовність, на думку автора, «досягається в ході моральної, психологічної, професійної та фізичної підготовки, $€$ результатом всебічного особистісного розвитку особистості з урахуванням вимог, зумовлених особливостями діяльності, професії». Проте в дослідженні відсутні критерії та показники, за якими проводиться визначення рівнів цієї готовності.

На думку В. Бочелюка [4], важливою умовою формування психологічної готовності майбутніх психологів до професійної діяльності з віктимними підлітками є наявність відповідних якостей, передусім схильностей і здібностей студентів до майбутньої діяльності. Автором визначено кроки готовності майбутніх психологів до професійної діяльності. Однак у змісті компонентів готовності із запобігання віктимній поведінці підлітків не відображено здатність до розуміння природи поведінки, діяльності та вчинків підлітків з неповної сім'ї.

Деякі дослідники [5] пропонують до структури психологічної готовності психолога до професійної діяльності включити функціонально пов'язані між собою та взаємозумовлені компоненти: мотиваційний (сукупність мотивів, адекватних цілям і завданням професійної діяльності); когнітивний (сукупність знань, необхідних для професійної діяльності); 
Напрями досліджень у контексті формування готовності психолога до професійної діяльності

\begin{tabular}{|c|c|c|c|}
\hline $\begin{array}{l}\text { Автор/роки } \\
\text { дослідження }\end{array}$ & Тематика & $\begin{array}{l}\text { Структурні компо- } \\
\text { ненти/зміст }\end{array}$ & $\begin{array}{l}\text { Розроблено/упроваджено/ } \\
\text { апробовано }\end{array}$ \\
\hline $\begin{array}{l}\text { М.В. Бадалова, } \\
2002 \text { р. [1] }\end{array}$ & $\begin{array}{l}\text { Формування в майбутніх } \\
\text { психологів інтелектуаль- } \\
\text { ної готовності до розв'я- } \\
\text { зування консультатив- } \\
\text { них завдань }\end{array}$ & $\begin{array}{l}\text { Рівні інтелектуальної } \\
\text { готовності: } \\
\text { - високий, } \\
\text { - середній, } \\
\text { - низький }\end{array}$ & $\begin{array}{l}\text { Психологічний комплекс } \\
\text { методик для визначення } \\
\text { рівня інтелектуальної готов- } \\
\text { ності майбутніх психологів до } \\
\text { розв'язання консультативних } \\
\text { завдань } \\
\end{array}$ \\
\hline $\begin{array}{l}\text { Н.П. Берегова, } \\
2009 \text { р. [3] }\end{array}$ & $\begin{array}{l}\text { Формування професій- } \\
\text { ної готовності майбутніх } \\
\text { психологів до роботи з } \\
\text { проблемними клієнтами }\end{array}$ & $\begin{array}{l}\text { - мотиваційний, } \\
\text { - когнітивний, } \\
\text { - операційно-діяльніс- } \\
\text { ний, } \\
\text { - емоційно-вольовий } \\
\end{array}$ & $\begin{array}{l}\text { Програма формування про- } \\
\text { фесійної готовності майбут- } \\
\text { ніх психологів до роботи } 3 \\
\text { проблемними клієнтами }\end{array}$ \\
\hline $\begin{array}{l}\text { В.В. Бочелюк, } \\
2014 \text { р. [4] }\end{array}$ & $\begin{array}{l}\text { Особливості готовності } \\
\text { майбутніх психологів до } \\
\text { роботи із запобігання } \\
\text { віктимній поведінці } \\
\text { підлітків } \\
\end{array}$ & $\begin{array}{l}\text { - мотиваційний, } \\
\text { - когнітивний, } \\
\text { - операційний, } \\
\text { - особистісний }\end{array}$ & $\begin{array}{l}\text { Модель формування готовно- } \\
\text { сті до роботи із запобігання } \\
\text { віктимній поведінці підлітків у } \\
\text { студентів-психологів }\end{array}$ \\
\hline $\begin{array}{l}\text { Т.О. Ковалькова, } \\
\text { 2013р. [10] }\end{array}$ & $\begin{array}{l}\text { Формування готовності } \\
\text { майбутніх психологів до } \\
\text { професійної діяльності в } \\
\text { авіаційній галузі }\end{array}$ & $\begin{array}{l}\text { - особистісний, } \\
\text { - когнітивний, } \\
\text { - інтерактивний, } \\
\text { - рефлексивний (оцін- } \\
\text { ний) }\end{array}$ & $\begin{array}{l}\text { Технології формування готов- } \\
\text { ності майбутніх психологів } \\
\text { до професійної діяльності } \\
\text { в авіаційній галузі в процесі } \\
\text { фахової підготовки } \\
\end{array}$ \\
\hline $\begin{array}{l}\text { А.І. Руденок, } \\
2013 \text { р. [15] }\end{array}$ & $\begin{array}{l}\text { Формування в майбутніх } \\
\text { психологів готовності до } \\
\text { запобігання сімейним } \\
\text { конфліктам і подолання } \\
\text { сімейних конфліктів } \\
\end{array}$ & $\begin{array}{l}\text { - мотиваційний, } \\
\text { - когнітивний, } \\
\text { - операційно-діяльніс- } \\
\text { ний, } \\
\text { - особистісний }\end{array}$ & $\begin{array}{l}\text { Тренінгова програма підви- } \\
\text { щення готовності майбутніх } \\
\text { психологів до запобігання } \\
\text { сімейним конфліктам і подо- } \\
\text { лання сімейних конфліктів } \\
\end{array}$ \\
\hline $\begin{array}{l}\text { Я.В. Чаплак, } \\
2011 \text { р. [17] }\end{array}$ & $\begin{array}{l}\text { Формування готовності } \\
\text { майбутніх практичних } \\
\text { психологів до консуль- } \\
\text { тативної взаємодії зі } \\
\text { старшокласниками, } \\
\text { схильними до правопо- } \\
\text { рушень }\end{array}$ & $\begin{array}{l}\text { - особистісний, } \\
\text { - теоретичний, } \\
\text { - практичний }\end{array}$ & $\begin{array}{l}\text { Програма та методика фор- } \\
\text { мування готовності психо- } \\
\text { лога до практичних справ }\end{array}$ \\
\hline $\begin{array}{l}\text { О.А. Черепєхіна, } \\
2006 \text { р. [19] }\end{array}$ & $\begin{array}{l}\text { Особливості психологіч- } \\
\text { ної готовності психологів } \\
\text { до професійної діяльно- } \\
\text { сті в спорті }\end{array}$ & $\begin{array}{l}\text { - ставлення до виду } \\
\text { діяльності, } \\
\text { - мотиви, } \\
\text { - знання про предмет, } \\
\text { - способи діяльності, } \\
\text { - навички й уміння їх } \\
\text { практично втілити }\end{array}$ & $\begin{array}{l}\text { Програма психокорекційної } \\
\text { роботи зі спортивними пси- } \\
\text { хологами щодо підвищення } \\
\text { рівня їх психологічної готов- } \\
\text { ності до професійної діяльно- } \\
\text { сті в спорті }\end{array}$ \\
\hline
\end{tabular}

операційний (сукупність умінь і навичок практичного вирішення професійних завдань); особистісний (сукупність важливих для психолога особистісних якостей). Водночас, на нашу думку, для глибшого відображення наповнення когнітивного компонента цієї готовності варто враховувати той факт, що для якісної взаємодії з клієнтом у професійній діяльності, сімейному психологу потрібні ґрунтовні знання з психології сім'ї, адже в будь-якому разі влив відбувається на продукт сімейної системи (дитину) або засновника її (дорослу людину), а також це те найближче середовище, вплив якого є незаперечним на особистість.

Вагомим внеском у напрямі дослідження $€$ роботи в контексті готовності психолога

\section{(1)}


роботу психолога щодо запобігання додатковим (ненормативним) сімейним кризам і конфліктам і подолання додаткових (ненормативних) сімейних криз і конфліктів у неповний сім'ях, таких як повторний шлюб, зведення дітей від попередніх шлюбів, народження спільної дитини тощо.

За О. Безлюдним, Т. Кобилянською [2], формування готовності майбутніх психологів до роботи із сім'ями підлітків у процесі професійної підготовки охоплює такі блоки та їх складники: методологічно-цільовий (мета, завдання, підходи, принципи), змістово-операційний (суб'єкти, етапи, зміст, форми, методи, технології), результативно-оцінний (критерії, рівні, результат), що відображають специфіку підготовки майбутніх психологів до роботи із сім'ями підлітків і забезпечують їхню готовність до здійснення цього процесу в професійній діяльності. Взаємодія психолога і сім'ї представлена в моделі трьома етапами: мотиваційним, операційним, оцінним. Проте поза увагою дослідників залишилася здатність психолога до розуміння природи поведінки, діяльності й вчинків членів студентських, неповних сімей.

Заслуговує на увагу в контексті розвідки робота Т. Левицької [11], де теоретично обґрунтовано поняття «психологічна готовність особи до створення сім'ї», яке відображає активно дійовий стан людини, її установку на створення сім'ї, а також знання основ сімейно-шлюбного життя. Дослідниця виділяє такі компоненти готовності: мотиваційний, когнітивний, операційний та особистісний, адже однією з причин утворення неповних сімей $€$ розпад шлюбу, де здебільшого першопричиною слугує непідготовленість шлюбних партнерів до створення сім'ї, невміння опанування нових ролей і відповідальності один за одного.

Як бачимо, обґрунтуванню провіднихпитань готовності майбутніх психологів до професійної діяльності присвячено праці багатьох науковців у галузі психології, але разом із тим спостерігаємо дефіцит вітчизняних досліджень, присвячених розробленню теоретичних основ і вдосконаленню практики професійної підготовки майбутніх психологів до роботи з неповними сім'ями.

Отже, аналіз літературних джерел щодо структури готовності до діяльності майбутніх психологів дає нам підстави стверджувати, що більшість науковців включає до структури цього складного інтегрального утворення чотири компоненти: 1) мотиваційний (спонукальний); 2) когнітивний (пізнавальний); 3) орієнтаційно-ціннісний(особистісний); 4) практично-операційний (діяльнісний). Формування феномена готовності здійснюється шляхом формування всіх її компонентів за домінуючої ролі того чи іншого компонента, залежно від виду діяльності в умовах спеціально організованого навчання й виховання, що спрямоване на оволодіння теоретичними знаннями, практичними вміннями та особистісним зростанням майбутнього психолога.

Узагальнення наукових думок дало нам змогу уточнити сутність поняття «Готовність майбутніх психологів до роботи з неповними сім'ями» як стійке впорядкування сукупності когнітивних процесів, відповідних психічних властивостей особистості фахівця, наявність у нього професійних знань із загальної та вікової психології, психології сім'ї, конфліктології, умінь, навичок, умотивованості, що дає змогу здійснювати комплексну, ефективну й успішну взаємодію психолога з членами неповних сімей.

Результати аналізу психологічних джерел щодо формування готовності майбутніх психологів до роботи з неповними сім'ями дають змогу визначити важливі структурні складники такої готовності, а саме: мотиваційно-ціннісний, когнітивно-пізнавальний, операційно-діяльнісний та особистісно-рефлексивний.

Щоб позбутися суб'єктивізму в дослідженні й визнання змісту компонентів у структурі готовності майбутніх психологів до роботи з неповними сім'ями, ми залучили експертів, які мають досвід практичної діяльності й консультативної роботи із сім'ями. Завданням експертів - із переліку ознак (знання, уміння, установки, особистісні якості), що найчастіше згадуються в працях дослідників, вибрати ті, які найбільше відображають наповненість того чи іншого структурного компонента. Для глибшого відображення змісту компонентів, експертам пропонувалося вказати в переліку ознак свої варіанти.

За результатами проведеної роботи нами визначено зміст кожного компонента зі структури готовності майбутніх психологів до роботи з неповними сім'ями. Зокрема, мотиваційно-ціннісний компонент у дослідженні відображає позитивна мотивація до професії сімейного психолога, мотивація досягти успіху в сімейному консультуванні, цінність взаємодії з різними типами сімей, інтерес до роботи з учасниками сімейних криз і конфліктів у неповний сім'ях, установка до здійснення психолого-педагогічної підтримки неповної сім'ї, мотивація до отримання нових знань про психолого-педагогічну підтримку неповних сімей, мотивація до підтримки позитивного соціально-психологічного клімату в неповних сім'ях, професійна установка на створення для неповної сім'ї умов для само- та взаємопідтримки, орієнтація на цінність сім'ї й високі досягнення в роботі з членами неповний сімей, прагнення до спілкування з дітьми та потреба надавати їм допомогу через гармонізацію внутрішньосімейних стосунків у неповний сім'ях, 
а також прагнення досягнути професійної майстерності в реалізації функцій та обов'язків у взаємодії з проблемною категорією сімей.

Що стосується когнітивно-пізнавального компоненту, його змістове наповнення відображають інтелектуально-розумовий потенціал, знання психологічної характеристики й особливостей неповних сімей, знання про психологічні проблеми неповної сім'ї, знання методів роботи з дітьми та підлітками з неповних сімей, спеціальні знання з курсів «Вікова психологія», «Конфліктологія», «Сімейна психологія», «Сексологія», знання й розуміння місця та ролі неповної сім'ї в процесі формування особистості, знання теорії та історії психолого-педагогічного захисту сім'ї й дітей, знання соціальних інститутів, які здійснюють психолого-педагогічну підтримку сім'ям, знання та розуміння соціальної значущості роботи психолога з неповною сім'єю, знання про обов'язки та функції сімейного психолога, здатність обробляти інформацію з різних галузей, а також здатність майбутнього фахівця до постійного професійного розвитку й самовдосконалення.

Важливими складниками операційно-діяльнісного компонента $є$ вміння аналізувати, синтезувати, порівнювати, узагальнювати інформацію, уміння визначати цілі, методи та форми роботи психолога з батьками і дітьми з неповних сімей, уміння здійснювати відбір засобів і форм для діяльності з членами неповних сімей, володіння способами та прийомами психологічної роботи з неповними сім'ями, уміння знаходити нестандартні методи та прийоми психолого-педагогічної дії на батьків і дітей з неповних сімей, уміння встановлювати контакт з дітьми та підлітками з неповних сімей, уміння планувати роботу з неповною сім'єю, уміння робити аналіз власної діяльності з метою її вдосконалення та підвищення своєї компетенції, уміння психолога ставити перед собою завдання й домагатися його реалізації, уміння вести документацію (протокол діагностичних досліджень, консультації тощо), діагностичні, організаційні, корекційні, дослідницькі, прогностичні вміння та навички для ефективної роботи з дітьми і дорослими членами неповних сімей, уміння управління своїми почуттями й емоціями при взаємодії з дітьми та дорослими з неповних сімей.

Особистісно-рефлексивний компонент включає здатність рефлексувати зміст своєї професійної діяльності в процесі роботи з неповною сім'єю, здатність творчо використовувати професійні знання в роботі з членами неповних сімей, ще й низку професійно-важливих особистісних властивостей і якостей (адекватна самооцінка, автентичність і гуманістичність, вербальний інтелект, винахідливість, високий рівень особистісної зрілості, витримка, відкритість, відповідальність, упевненість, готовність до нових ситуацій, дисциплінованість, емпатійність, привітність, енергійність, ентузіазм, зосередженість на меті, ініціативність, кмітливість, компетентність, креативність, комунікабельність, позитивна спрямованість, критичність мислення, моральність, надійність, об'єктивність, оперативність, почуття гумору, прагнення до досягнень, самоконтроль, стресостійкість, терпимість, толерантність, цілеспрямованість і зібраність).

Висновки 3 проведеного дослідження. Отже, нами з'ясовано, що поняття «готовність майбутніх психологів до роботи з неповними сім'ями» відображає вмотивованість до професійної діяльності до роботи з неповними сім'ями, сукупність когнітивних процесів як результат засвоєння змісту освіти, наявність професійних знань із загальної та вікової психології, психології сім'ї, конфліктології, умінь, навичок, методів, спрямованих на допомогу членам неповних сімей, а також відповідних психічних властивостей особистості фахівця, що дає змогу здійснювати комплексну, ефективну та успішну взаємодію психолога з членами неповних сімей.

Уточнено компоненти, а саме: мотиваційно-ціннісний, когнітивно-пізнавальний, операційно-діяльнісний, особистісно-рефлексивний - і визначено ознаки готовності, які відображають змістове навантаження кожного компонента готовності майбутніх психологів до роботи з неповними сім'ями.

Надалі вважаємо за необхідне виявлення чинників і шляхів, які б забезпечували ефективність процесу формування готовності майбутніх психологів до роботи з неповними сім'ями, що й слугує перспективою подальших розвідок у цьому напрямі.

\section{ЛITEРATУРА:}

1. Бадалова М.В. Профессиональная рефлексия практических психологов: опыт изучения. Практична психологія та соціальна робота. 2002. № 4. С. 28-30. URL: http://oaji.net/articles/2014/983-1415344555.pdf.

2. Безлюдний О.І., Кобилянська Т.В. Модель формування готовності майбутніх психологів до роботи із сім'ями підлітків у процесі професійної підготовки. Балканско научно обозрение. 2017. № 1. C. 9-14.

3. Берегова Н.П. Формування просресійної готовності майбутніх психологів до роботи з проблемними клієнтами : автореф. дис. ... канд. психол. наук : 19.00.07 «Педагогічна та вікова психологія» / Національна академія ДПСУ ім. Б. Хмельницького. Хмельницький, 2009. 20 с.

4. Бочелюк В.В. Особливості готовності майбутніх психологів до роботи з попередження віктимної поведінки підлітків. Вісник Харківського національного педагогічного університету імені Г.С. Сковороди. Серія «Психологія». 2014. № 48. С. 12-22. URL: http://nbuv.gov.ua/UJRN/VKhnpu_psykhol_2014_48_4. 
5. Бочелюк В.Й. Психологія: вступ до спеціальності. Київ : Центр навч. літератури, 2007. 287 с.

6. Дурай-Новакова К.М. Формирование профессиональной готовности студентов к педагогической деятельности : автореср. дис. ... докт. пед. наук. Москва, 1983. 32 с.

7. Дьяченко М.Н., Кандибович Л.А. Психологические проблемы готовности в деятельности. Минск : Издательство БГУ, 1996. 175 с.

8. Зеер Э., Симанюк Э. Компетентносный подход к модернизации профессионального образования. Высшее образование в России. 2005. № 4. С. 23-30.

9. Зубкова Т.С. Организация и содержание работы по социальной защите женщин, детей и семей. Неполные семьи. Москва, 2003. 75-80 с.

10. Ковалькова Т.О. Проблема фрормування структури готовності майбутніх психологів до професійної діяльності в авіаційній галузі. Проблеми сучасної педагогічної освіти. Серія «Педагогіка і психологія». 2013. № 39 (2). С. 99-103. URL: http://nbuv.gov. ua/UJRN/pspo 2013 (2) 20.

11. Потапчук Є.М., Левицька Т.Л. Готовність студентів вищого навчального закладу до створення стабільної сім'ї як психолого-педагогічна проблема. Науковий часопис НПу імені М.П. Драгоманова. Серія № 12 «Психологічні науки» : збірник наукових праць / відпов. ред. Л.В. Долинська. Київ, 2007. № 16 (40). 89-94 c.

12. Максименко С.Д., Пелех О.М. Фахівця потрібно моделювати. Рідна школа. 1994. № 3-4. С. 68-72.

13. Панок В.Г. Основні напрями професійного становлення особистості практичного психолога у вищій школі. Практична психологія та сочіальна робота. 2003. № 4. 14 c.

14. Рибалка В.В. Психологічна культура особистості у професійній підготовці та діяльності прак- тичного психолога. Проблеми підготовки і підвищення кваліфрікації практичних психологів у вищих навчальних закладах. Київ : Ніка-Центр, 2002. С. 29-32.

15. Руденок А.І. Аналіз результатів фрормування готовності майбутніх психологів до запобігання та подолання сімейних конфліктів. Збірник наукових праць Національної академії Державної прикордонної служби України. Серія «Педагогічні та психологічні науки». 2013. № 1. С. 514-524. URL: http://nbuv.gov.ua/UJRN/znpnapv_ppn_2013_1_53.

16. Сластенин В.А., Исаев И.Ф., Шиянов Е.Н. Педагогика : учебное пособие для студентов высших педагогических учебных заведений. Москва : Издательский центр «Академия», 2002. 576 с.

17. Чаплак Я.В., Гаркавенко Н.В., Солійчук І.І. Формування готовності майбутніх практичних психологів до консультативної взаємодії зі старшокласниками, схильними до правопорушень : монографрія. Чернівці, 2011. С. 232.

18. Чепелєва Н.В. Теоретичне обґрунтування моделі особистості практичного психолога. Психологія : збірник наукових праць. 1998. № III. С. 35-41.

19. Черепєхіна О.А. Особливості психологічної готовності психологів до професійної діяльності у спорті : автореф. дис. ... канд. психол. наук : 19.00.01. Київ, 2006. 23 с.

20. Шульга А.В. Підготовка майбутнього вчителя початкової школи до роботи з батьками молодших школярів 3 неповних сімей : автореф. дис. ... канд. пед. наук : 13.00.04. Київ, 2017. 20 с.

21. Юрченко І.В. Психологічна допомога фуннціонально неповним сім'ям в умовах навчально-виховного комплексу І ступеня : автореф. дис. ... канд. психол. наук : 19.00.07. Івано-Франківськ, 2008. 20 с. 